\title{
A SPECTRAL METHOD OF LITHOFACIES DIFFERENTIATION WITHIN A HYDROCARBON RESERVIOR UNIT USING SEISMIC AND WELL DATA FROM TOMBOY FIELD NIGER DELTA
}

\author{
Eze Stanley*1,2, Emujakporue .O. Godwin ${ }^{3}$, Williams Ofuyah ${ }^{4}$, Nnorom .S. Lotanna ${ }^{4}$ \\ ${ }^{1}$ Department of Geology, University of Port Harcourt, Rivers State, Nigeria \\ ${ }^{2}$ Department of Marine Geology, Nigeria Maritime University Warri South-West Delta State. \\ ${ }^{3}$ Department of Physics, University of Port Harcourt, Rivers State, Nigeria \\ ${ }^{4}$ Department of Earth Sciences, Federal University of Petroleum Resources, Effurun, Nigeria \\ *Corresponding Author: Eze Stanley
}

\begin{abstract}
Seismic facies analysis is a key component of Seismic interpretation workflow, as much information on depositional process, environment, reservoir architecture and potential can be determined from the seismic data. This enhances the seismic visibility of subtle stratigraphic features, and prediction of new prospects for drilling due to lateral continuity of sand bodies (the hydrocarbon reservoir) deposited within the sedimentary column. This study presents the results of the application of seismic amplitude inversion and spectral decomposition to differentiate lithofacies within a thin-sand reservoir and show their lateral and vertical continuity using amplitudederived attributes (rock properties) in the interpretation of 3D seismic and well log data from "TOMBOY" field Niger Delta. A thin-sand reservoir was delineated from lithologic log signatures within the interval 11,135.61$11,210.35 \mathrm{ft}$ which corresponds to the time window $2.752-2.768 \mathrm{secs}$ on the seismic data along an arbitrary line drawn to connect the six wells (01-06) in the field. Crossplot of acoustic impedance against density across the reservoir bed showed three compartments interpreted as gas filled sand, oil filled sand and shale. The interpretation was enhanced via spectral analysis by computing frequency maps of acoustic impedance, density and velocity using discrete Fourier transform (DFT) technique at top $(2.752 \mathrm{sec})$ of the reservoir in terms of magnitude, phase and frequency. Phase response for the three attributes (acoustic impedance, density and velocity) showed lateral continuity and discontinuity of sand lithofacies at the various well locations which were not evident on their original amplitude time slice, while frequency response showed bed thickness, with low frequency indicating presence of hydrocarbon or sand rich beddings, while high frequency indicates thin shale beddings. It was observed that the top $(2.752 \mathrm{sec})$ of the reservoir for wells $02,05,01$ and 04 showed low frequency values for the three attributes (acoustic impedance, density and velocity) which indicates potential zones for hydrocarbon production and development in the field, while wells 03 and 06 within the same time slice $(2.752 \mathrm{sec})$ showed a higher value in acoustic impedance frequency, density frequency and velocity frequency and suggests the presence of thin shale facies at the top $(2.752 \mathrm{sec})$ of the thin-sand reservoir. By defining the lateral and vertical continuity of sand facies within the reservoir bed, hydrocarbon fairways were better defined and knowledge of this can be incorporated into drilling decisions for field development. The results gave enhanced structural disposition of the reservoir bed and more insights into the variation of sand lithofacies with depth.
\end{abstract}

Keywords: Lithofacies, Amplitude inversion, Geologic transform, Seismic attributes, Cross plots and Spectral decomposition.

DOI: $10.7176 / \mathrm{JEES} / 9-3-14$

Publication date:March $31^{\text {st }} 2019$

\section{INTRODUCTION}

A facies is a body of rock with specific characteristics, which can be any observable attribute of a rock such as overall appearance, composition, or condition of formation. Seismic facies are mappable 3D seismic units composed of groups of reflections whose parameters differ from those of adjacent facies unit (Mitchum et al., 1997). Seismic facies interpretation is the geologic interpretation of seismic attributes (coherence, amplitude, frequency, and interval velocity); these attributes determine variations of seismic properties within individual seismic sequences in order to determine lateral and vertical continuity in lithofacies and fluid type. (Mitchum et. al., 1997). Lithofacies differentiation within a hydrocarbon reservoir unit is the lateral and vertical distribution of rock facies within the reservoir. This technique is aimed at improving reservoir characterization to optimize hydrocarbon production (Ofuyah et al., 2015). 
The seismic reflection method ever since its discovery in the late $1920 \mathrm{~s}$, has and still remains one of the most effective tools in the search for hydrocarbons. Reflections are due to contrast in acoustic impedance in the subsurface caused by difference in physical properties of rocks which can be density and compressional wave velocity and can be interpreted in terms of lithology, porosity and porefill (Hansen et al., 2008, Ukaigwe, 2000). The ultimate goal of the seismic method is to delineate structural and stratigraphic structures suitable for hydrocarbon accumulations. Structural traps are usually more evident in the seismic records, while Stratigraphic traps on the other hand are not so evident but subtle on seismic records (Telford et al., 1990, Yilmaz, 2001). With advancement in technologies, the use of seismic data has extended to other areas such as stratigraphic imaging, pore-fluid estimation, and lithofacies differentiation e.t.c, and these applications have led to the discovery of huge oil and gas reserves often confined within subtle stratigraphic features. These subtle stratigraphic features are thin beds defined by Widess (1973) as having a thickness of less than a quarter of the wavelength of the dominant frequency present. Thin beds usually depict gradual and gentle geologic variations that are not so obvious in conventional seismic interpretation because they fall below the limit of seismic resolution. Seismic analysis workflow can help improve vertical resolution and identify thin beds on seismic reflection data, which can lead to accurate stratigraphic interpretation (Castagna et al., 2003). In analyzing seismic facies (lithofacies as it were), seismic attributes are usually combined to obtain meaningful results for reservoir characterization. Seismic attribute was introduced as part of the seismic interpretation process in the early 1970's, and since then has remained the most reliable interpretation tool for reservoir characterization and lithofacies analysis from seismic data. This is because seismic attributes can be used to predict rock properties which are sensitive to lithology changes within the subsurface. The process of computing rock properties from seismic attributes is called "inversion". Acoustic impedance inversion involves conversion of seismic traces to a reflection coefficient time series, and then into acoustic impedance (Lavergne and William, 1977; Lindseth, 1979). These impedance traces can enhance accuracy of interpretation and correlation with properties measured in well logs. In this sense, inversion can be considered a sophisticated method of integrating well logs and seismic data for thin bed delineation, lithofacies differentiation within thin beds, and reservoir characterization. Lithofacies differentiation within hydrocarbon reservoirs before now have been done by formation evaluation using geophysical well logs, facies associated with fluid separation using well logs, and hydrocarbon reservoir mapping (Opara 2010; Aigbedion and Iyayi, 2007; Adeoye and Enikanselu, 2009). The use of seismic amplitude-derived attributes and well data for Lithofacies differentiation within a reservoir unit (such as thin beddings) have not been properly documented in literatures because thin beds often fall below the level of seismic resolution (Castagna et al., 2003). This study presents the results of a new technique which uses seismic amplitude-derived attributes (interval velocity, density, acoustic impedance \& porosity) and well logs for lithofacies differentiation across a thin-sand reservoir bed. The technique uses amplitude inversion of seismic trace and geologic transform of seismic amplitude derived attributes followed by spectral decomposition using discrete Fourier transform (DFT) technique to increase the seismic bandwidth of the seismic-derived attributes to improve their resolution in spectral domain. This will in implication contribute to the existing debate on thin bed analysis, lithofacies differentiation and presence of lateral continuity of sands. The study area is Tomboy field located within the Niger Delta.

\section{GEOLOGIC SETTING}

The field under study is "TOMBOY FIELD" located in a transitional environment around Port Harcourt axis of the Niger delta. The Niger Delta is situated in the Gulf of Guinea in the West coast of Africa. 
IISTE

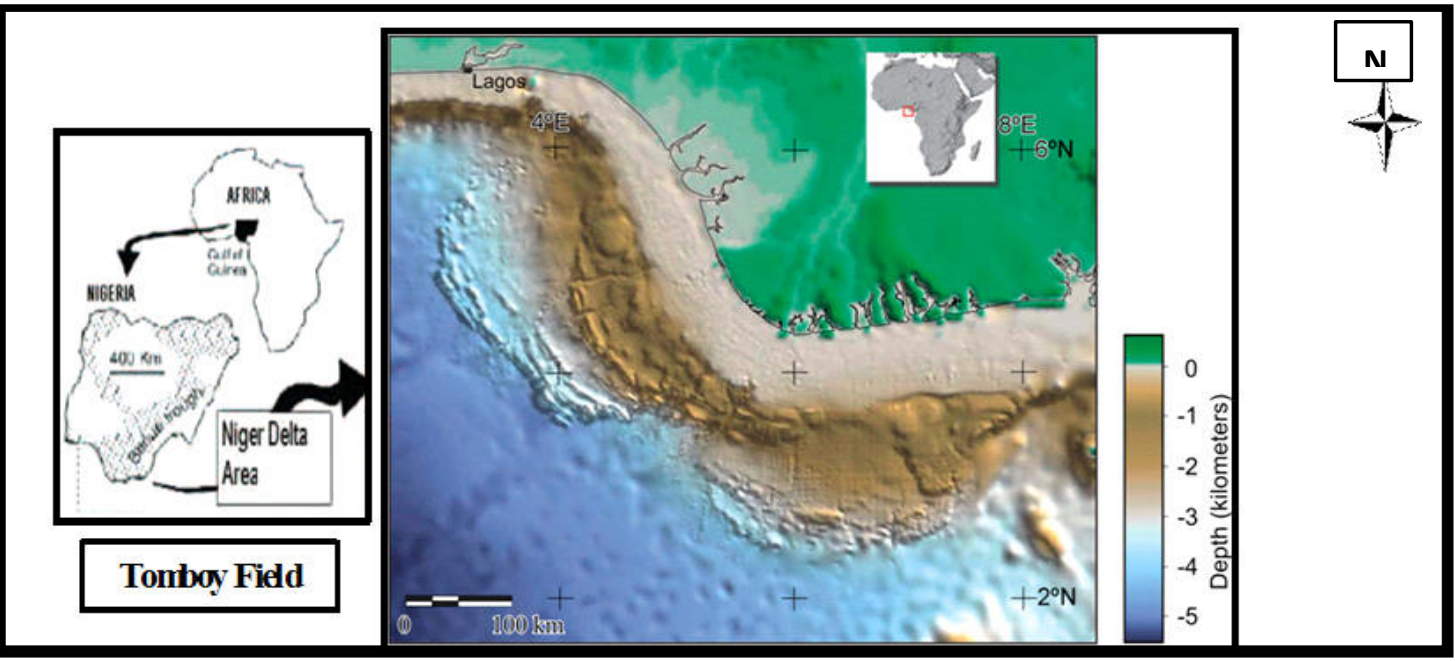

Figure 1: Tomboy field, Niger Delta, sShowing the Bathymetric sea-floor image of the region, (After Smith and Sandwell, 1997, as cited in Corredor et al., 2005).

The Niger Delta basin evolved in early tertiary times where rapid deposition and subsidence have occurred over time (Doust and Omatsola, 1990). Generally, the delta prograded over the subsidizing continental-oceanic lithospheric transition zone, and during the Oligocene spread into oceanic crust of the Gulf of Guinea (Short and Stauble 1967). Thickness of sediments in the Niger Delta averages at $12 \mathrm{~km}$ covering a total area of about 140,000 $\mathrm{km}^{2}$. The early Niger Delta is interpreted as being a river-dominated delta, however the post-Oligocene delta is a typical wave-dominated delta with well-developed shoreface sands, beach ridges, tidal channels, mangrove and freshwater swamps. It is one of the world's largest deltas and shows an overall upward transition from marine shales (Akata Formation) through a sand-shale paralic interval (Agbada Formation) to continental sands of the Benin Formation. Depending on relative sea level changes, local subsidence and sediment supply, the delta experiences episodes of regressions and transgressions. Tectonics in the Niger delta rifting diminished in the Late Cretaceous. After rifting ceased, gravity tectonics became the primary deformational process. The stratigraphic sequence of the Niger Delta comprises three broad lithostratigraphic units namely; a continental shallow massive sand sequence - the Benin Formation, a coastal marine sequence of alternating sands and shales - the Agbada Formation and a basal marine shale unit-the Akata Formation. The Akata Formation consists of clays and shaleswith minor sand alternations. The sediments were deposited in prodelta environments. The sand percentage here is generally less than $30 \%$. The Agbada Formation consists of alternating sand and shales representing sediments of the transitional environment comprising the lower delta plain (mangrove swamps, floodplain and marsh) and the coastal barrier and fluvio marine realms. The sand percentage within the Agbada Formation varies from 30 to $70 \%$, which results from the large number of depositional off lap cycles. A complete cycle generally consists of thin fossiliferous transgressive marine sand, followed by an offlap sequence which commences with marine shale and continues with laminated fluvio marine sediments followed by barriers and/or fluviatile sediments terminated by another transgression cycle (Weber and Daukoru 1975; Ejedawe, 1981). The Benin Formation is characterized by high sand percentage $(70-100 \%)$ and forms the top layer of the Niger Delta depositional sequence. The massive sands were deposited in continental environment comprising the fluvial realms (braided and meandering systems) of the upper delta plain. 
SOUTHWEST

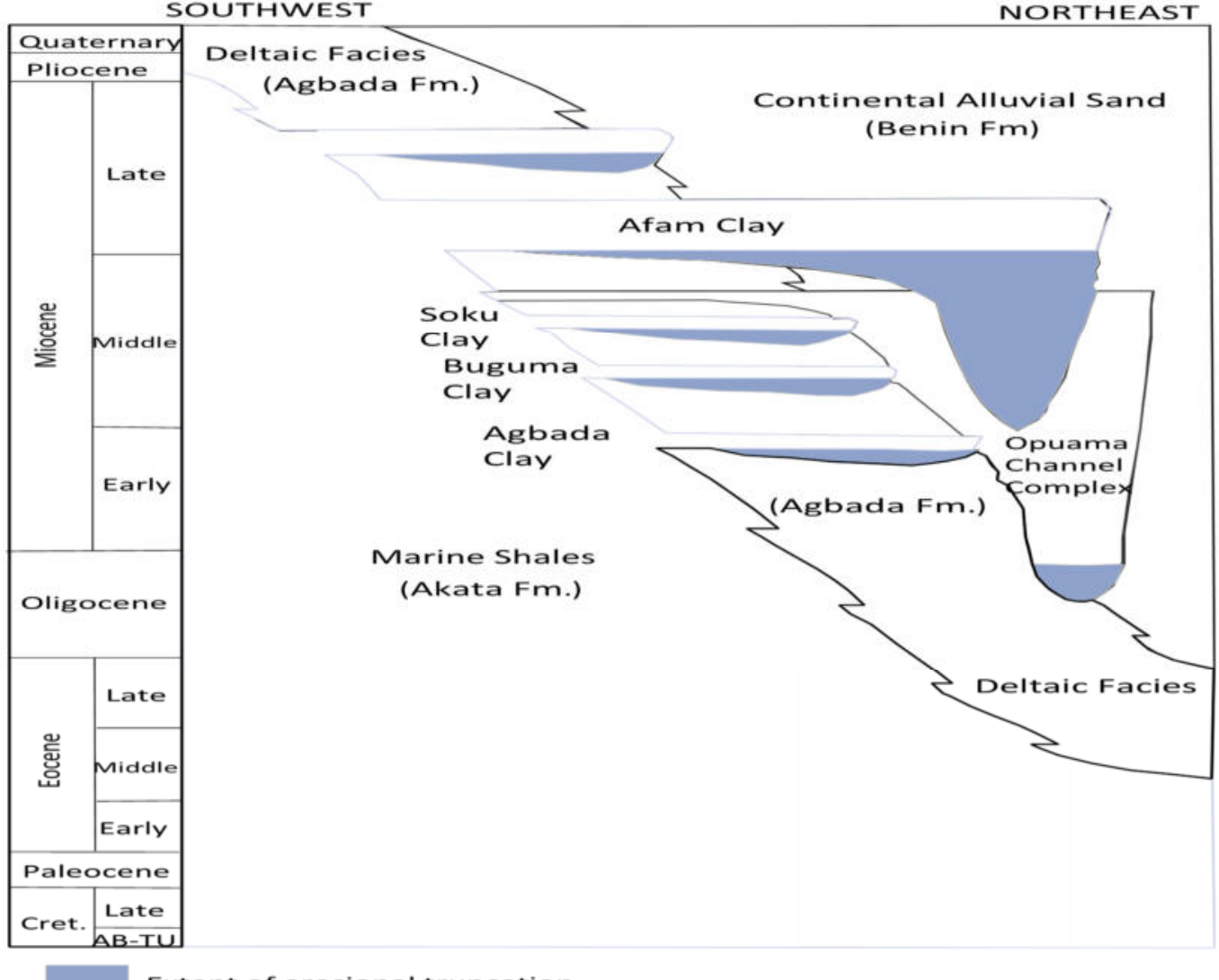

Extent of erosional truncation

Figure 2: Stratigraphic column showing the three formations of the Niger Delta. (Modified from Doust and Omatsola (1989).

Petroleum occurs within the Agbada Formation of the Niger Delta basin however, several directional trends form an "oil-rich belt" having the largest field and lowest gas:oil ratio (Ejedawe, 1981; Evamy et al., 1978; Doust and Omatsola, 1990). Hydrocarbon distribution was originally attributed to timing of trap formation relative to petroleum migration (earlier landward structures trapped earlier migrating oil). 


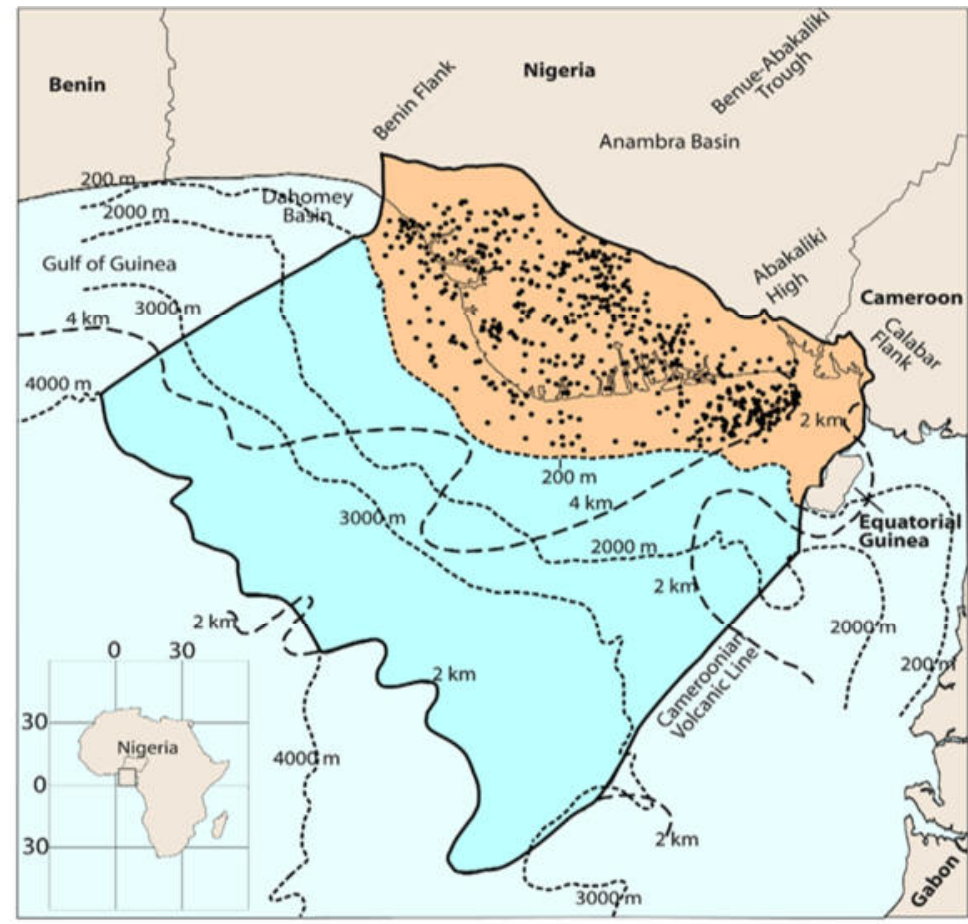

Explanation

- Province 7192 boundary

202 ro Bathymetric contour (m)

$2 \mathrm{~km}$ Sediment thickness $(\mathrm{km})$

- Center of gas or oil field

Minimum petroleum system

Maximum petroleum system

Figure 3: Map of the Niger Delta showing Province outline (Maximum petroleum system); bounding structural features; minimum petroleum system as defined by oil and gas field center points; 200, 2000, 3000, and 4000m bathymetric contours; and 2 to 4km sediment thickness (After Petro consultant, 1996a).

\section{THEORY OF SEISMIC INVERSION AND GEOLOGIC TRANSFORM 3.1 Seismic amplitude inversion}

In this study acoustic impedance and interval velocity (Vi) were derived from seismic amplitude via seismic inversion technique Boisse (1978). The instantaneous amplitude (envelope or reflection strength), and its derivatives, are key seismic attributes which are diagnostic in resolving hydrocarbon bearing reservoir units. Amplitude inversion is a 1-D inversion of seismic data which visualizes the earth as made up of composite of layers at each CMP location. Each composite layer has a characteristic density, velocity, and layer thickness and similar two-way time intervals. The procedure that converts estimates of reflection coefficients into an image of acoustic impedance with depth has been discussed meticulously by Lavergne and William (1977), Lindseth (1979) and Dobrin (1988). 
For a normal incident acoustic pressure wave, the reflection coefficients for layer interfaces are related to acoustic impedance by:

$$
\mathrm{RC}=\frac{\rho_{i+1} V_{i+1}-\rho_{i} V_{i}}{\rho_{i+1} V_{i+1}+\rho_{i} V_{i}}
$$

Where $R C$ is the reflection coefficient of the $\mathrm{i}^{\text {th }}$ interface and $\rho_{\mathrm{i}} \mathrm{V}_{\mathrm{i}}$ is the acoustic impedance of the $\mathrm{i}^{\text {th }}$ layer. Therefore the acoustic impedance for the next $(i+1)^{\text {th }}$ layer is,

$$
\rho_{i+1} V_{i+1}=\rho_{i} V_{i} \frac{(1+R C)}{(1-R C)}
$$

In this study, seismic amplitude traces were extracted from the geologic window defined from well logs. The true reflection coefficient $(R C)$ was computed from trace extracted at well with acoustic log as control and from the $R C$ values. A scaling factor $[\mathrm{K}]$ was inferred to calculate erroneous $\mathrm{RC}_{\mathrm{e}}$ values from the trace extracted at other locations on the seismic data where there are no wells.

Therefore the scaling factor $\mathrm{K}$ is given by;

$$
K=\frac{A}{R C}
$$

Where $\mathrm{A}$ is the trace amplitude data,

$$
R C e=\frac{K}{A o}
$$

Where Ao is the seismic amplitude values from traces extracted from the geologic window under analysis.

Finally the estimated interval velocity is;

$$
V_{i+1}=\frac{(\rho i v i)}{\rho i+1} \frac{(1+R C e)}{(1-R C e)}
$$

Where $\mathrm{RC}_{\mathrm{e}}$ is the amplitude dependent reflection co-efficient.

In the absence of density values, the internal velocity can be estimated by equating the density parameters, hence the interval velocity is

$$
V_{i+1}=V_{i} \frac{(1+R C e)}{(1-R C e)}
$$

Equation (6) was in turn used to determine the interval velocity at the reservoir window.

\subsection{Geologic transforms}

These are transforms in time domain used in the estimation of dense 3-D volume of pseudo-sections from 3-D seismic data (amplitude) and well logs using neutral networks, statistical or non-linear estimator and calibration techniques. However, the process to go from seismic data and existing well logs to a dense 3-D cube of pseudowell logs depends on the appraisal of many critical sub-process and non-trivial choices. These have not been well documented in literatures (Branchs and Michelena, 2002). The technique offers important 
advantages such as the ability to incorporate spatial and temporal variations in the relationship between seismic data and well logs. In this study, the following pseudo-well logs were estimated:

\subsubsection{Pseudo Acoustic impedance log}

Gardner et al., (1974) showed an empirical linear relationship between acoustic impedance $(\rho V)$ and interval velocity $(\mathrm{V})$ given as

$$
\rho V=(\mathrm{V}-3460) / 0.308
$$

Where $\mathrm{V}$ is interval velocity in $\mathrm{ft} / \mathrm{sec}$, and $\rho \mathrm{v}$ is the acoustic impedance value. A reflection coefficient sequence $\mathrm{RC}_{\mathrm{i}}$, can be computed from a borehole sonic log. How e ver, if density information is available (conditional), a better approximation to the reflection coefficient can be obtained using

$$
\mathrm{RC}_{\mathrm{i}}=\frac{\rho_{i+1} V_{i+1}-\rho_{i} V_{i}}{\rho_{i+1} V_{i+1}+\rho_{i} V_{i}}
$$

Where $\rho$ and $V$ are the density and velocity at specified time index. The inversion of seismic data is board upon rearranging the terms in the $\left(i^{\text {th }}\right)$ interface to give the acoustic impedance log series.

\subsubsection{Pseudo-Porosity log}

The relation for the computation of pseudo-porosity log series is:

$$
\phi=100 * \mathrm{C}\left(t_{\log }-t_{m a}\right) / t \log
$$

This empirical equationis based on field observations (Schlumberger, 1987).

Where;

$\mathrm{C}=0.67$ (correction term)

$\varphi=$ Sonic porosity $(\%)$

tlog $=$ Transit time obtained from $\log$

tma $=$ Transit time of the matrix $(55.5 \mu \mathrm{sec} / \mathrm{ft}$ for sandstone $)$.

This relation was adopted for use because of its applicability to uncompacted sands in the tertiary Niger Delta, where this study is being carried out. In terms of significance, porosity usually decreases with increasing velocity although the velocity-porosity relations are not always unique.

\subsubsection{Pseudo-Density log}

The pseudo-density log series was estimated from acoustic-impedance log from the expressions:

$$
\rho_{\text {impedance }}=\frac{\text { Acoustic impedance }(\rho \mathrm{V})}{\operatorname{Velocity}(\mathrm{V})}
$$

The density log series also called Acoustic-Impedance derived density was found closets to the well log density values (in time), and was therefore used in this study.

\section{METHODOLOGY}

The data provided for this study consists of seismic data (measured field amplitude) and a suite of well logs which includes, gamma, resistivity, spontaneous, density, sonic and deep lateral logs f o r s i x (6) we $11 \mathrm{~s}$ within "TOMBOY-Field" Niger Delta w ith well- 04 as the reference we 11. On the basis of lithologic signatures read from the suite of well logs, several thin sand reservoirs exists within Well-04. Reservoir window 
was taken at depths of 11,135.61-11,210.35ft which corresponds to 2.752-2.768 seconds, following a depth to time conversion done with velocity at $4046.37 \mathrm{ft} / \mathrm{s}$. Crossplot of measured and derived density versus acoustic impedance was made across the reservoir bed using Gnuplot programme, to check for fluid content distribution. Seismic data (field amplitude) was used to invert for acoustic impedance and interval velocity using seismic amplitude inversion technique discussed in section 3.1. Geologic transforms were equally used to compute rock attributes such as acoustic impedance, density and porosity at top $(2.752 \mathrm{sec})$ of the reservoir. Spectral decomposition analysis using the discrete Fourier transform technique (DFT) was applied to transform the amplitude derived attributes in time into frequency and their mean spectral response were obtained in terms of magnitude, phase and frequency at top $(2.752 \mathrm{sec})$ of the reservoir. The comparison was made between the attributes in time and their frequency equivalents, and interpreted for lithofacies differentiation and lateral continuity of sands within the top of the reservoir. The geologic transforms were computed using written program scripts within MATLAB software. The entire seismic and well data were initially loaded into kingdom suite software (Shell platform), from which the base map, seismic section and digital seismic data were extracted and used.

\section{RESULTS}

This section presents the results obtained and detailed explanations on how the observed results were achieved. Furthermore, the base map of the survey area showing the grid of 3-D seismic acquisition and the various wells is shown in figure 4. Well-04 shown as (TMB 04 plan at coordinate $5975 ; 1612$ on the base map) is the reference well. 


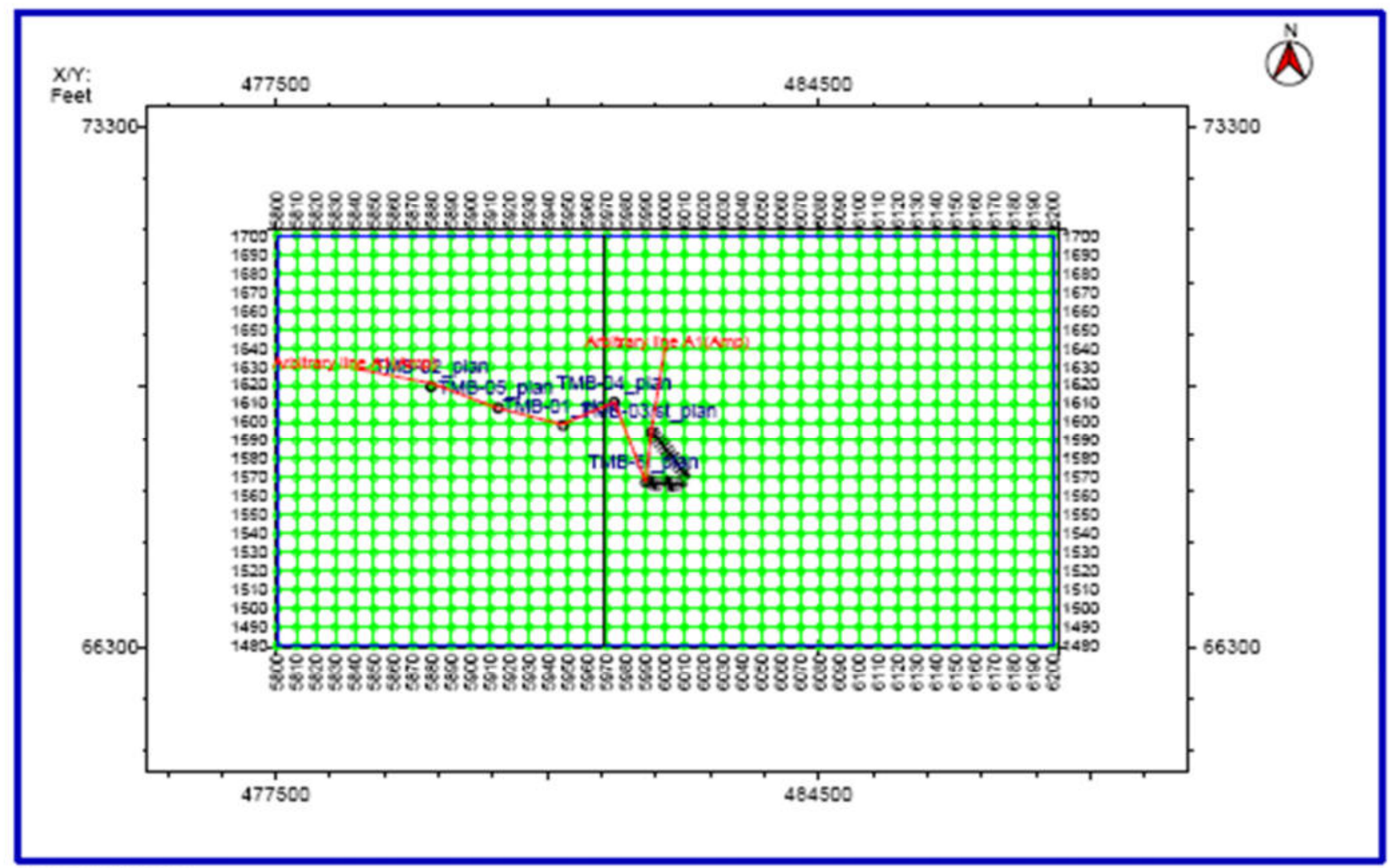

$02 / 04 / 07 \quad 15: 52: 18$

Figure 4: Base map of study area showing all the wells. The red line is an arbitrary line joining the wells which are in black circle. TMB-04 plan is the reference well. 


\subsection{LOG ANALYSIS}

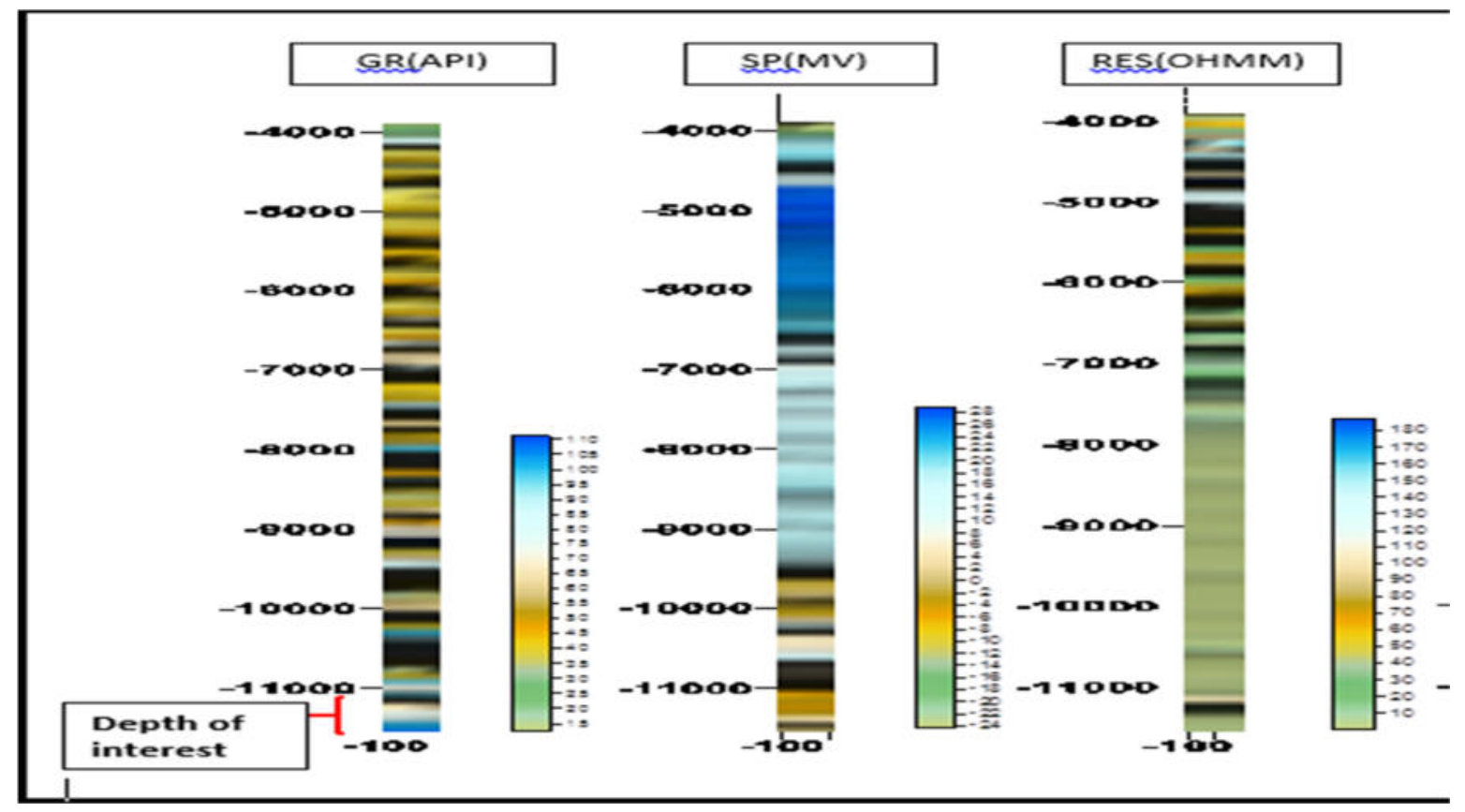

Figure 5 (a): A plot of GR, SP, and Resistivity log for well-04 (reference well). The depth of interest is 11,135.61$11,210.35 \mathrm{ft}$.

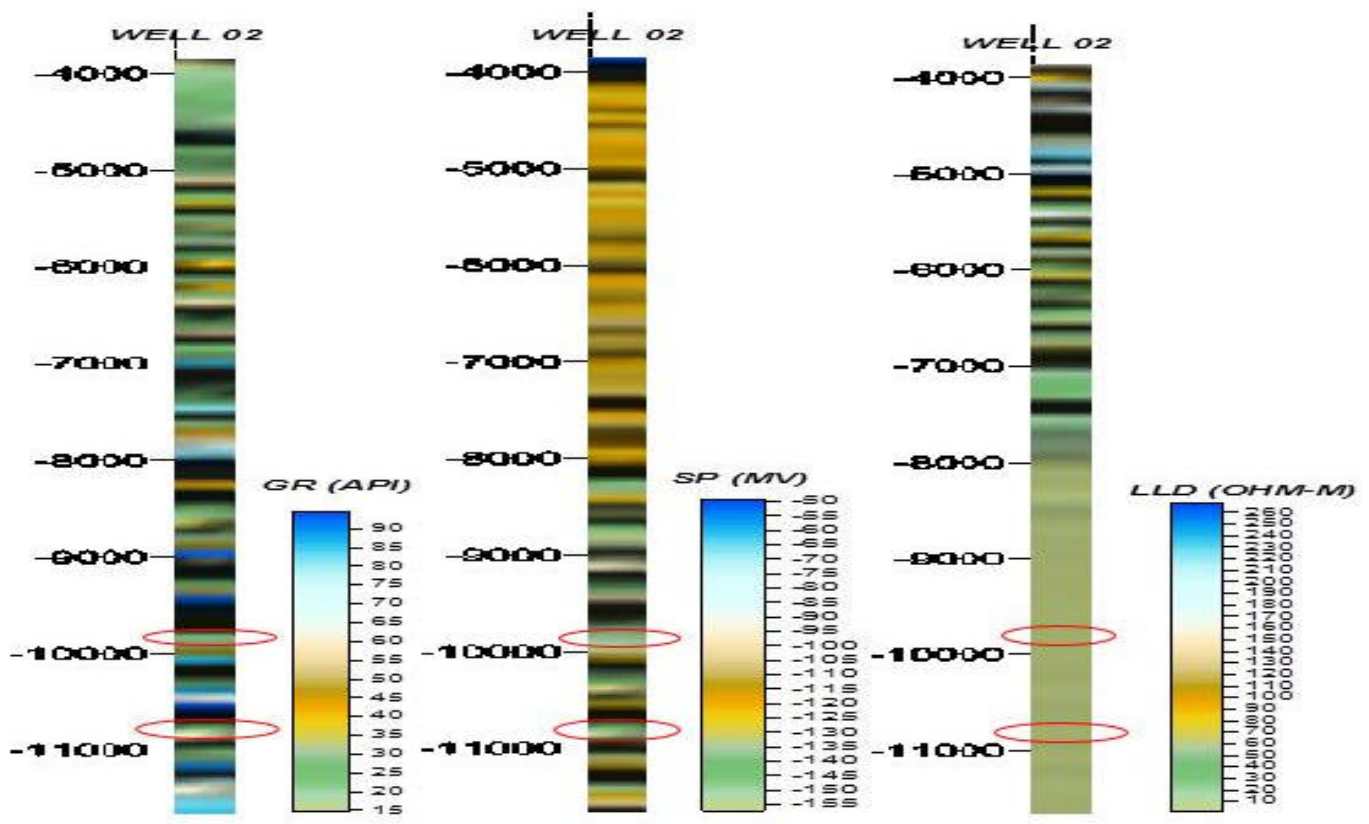

Figure 5 (b): Plot of GR, SP and LLD of Well 02. The red circled spot indicates a sand Formation. This was chosen as both the GR, SP and LLD agrees within same depth interval. 


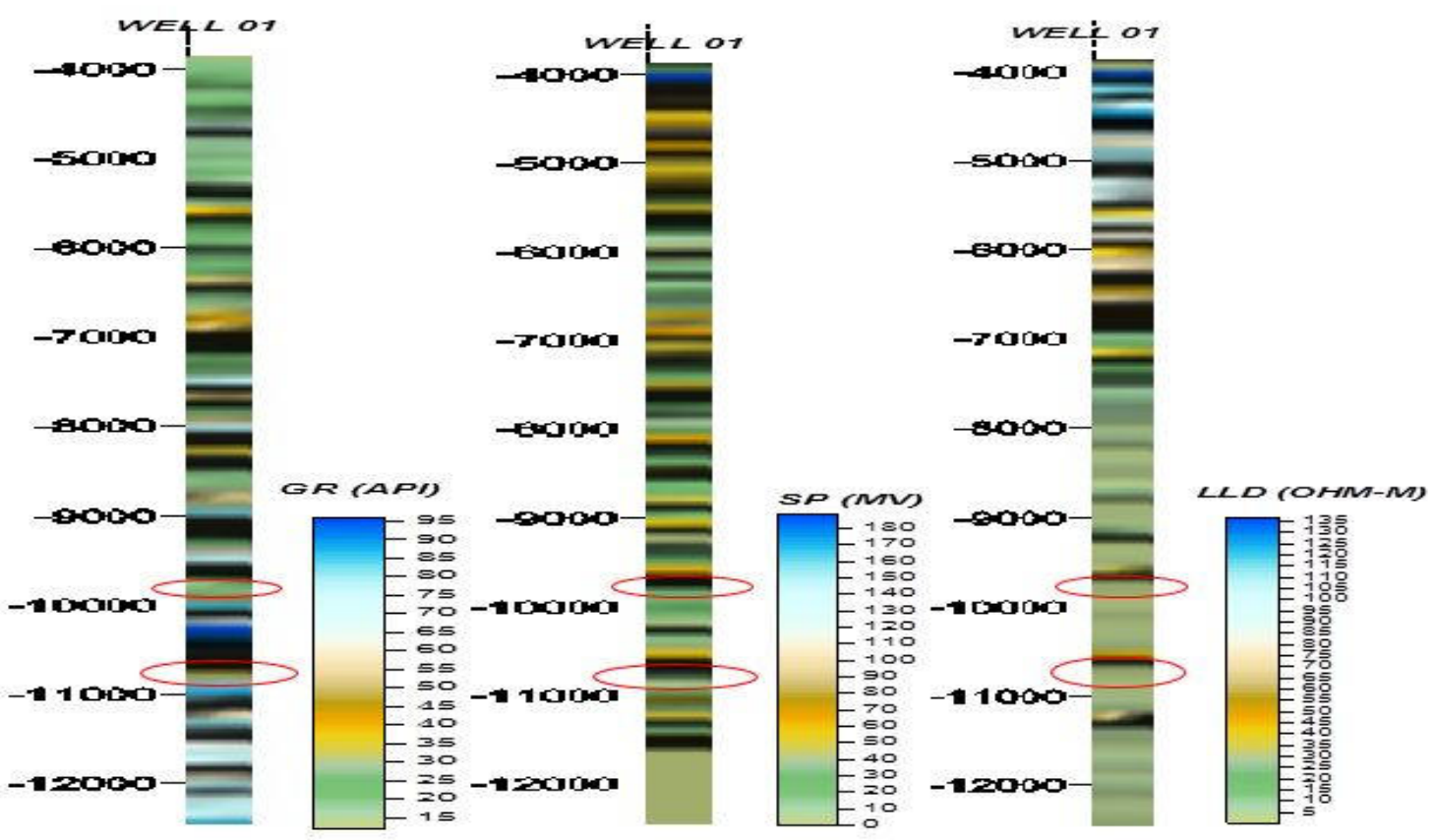

Figure 5 (c): Plot of GR, SP and LLD of Well 01. The red circled spot shows the depth interval picked earlier in well 02 .
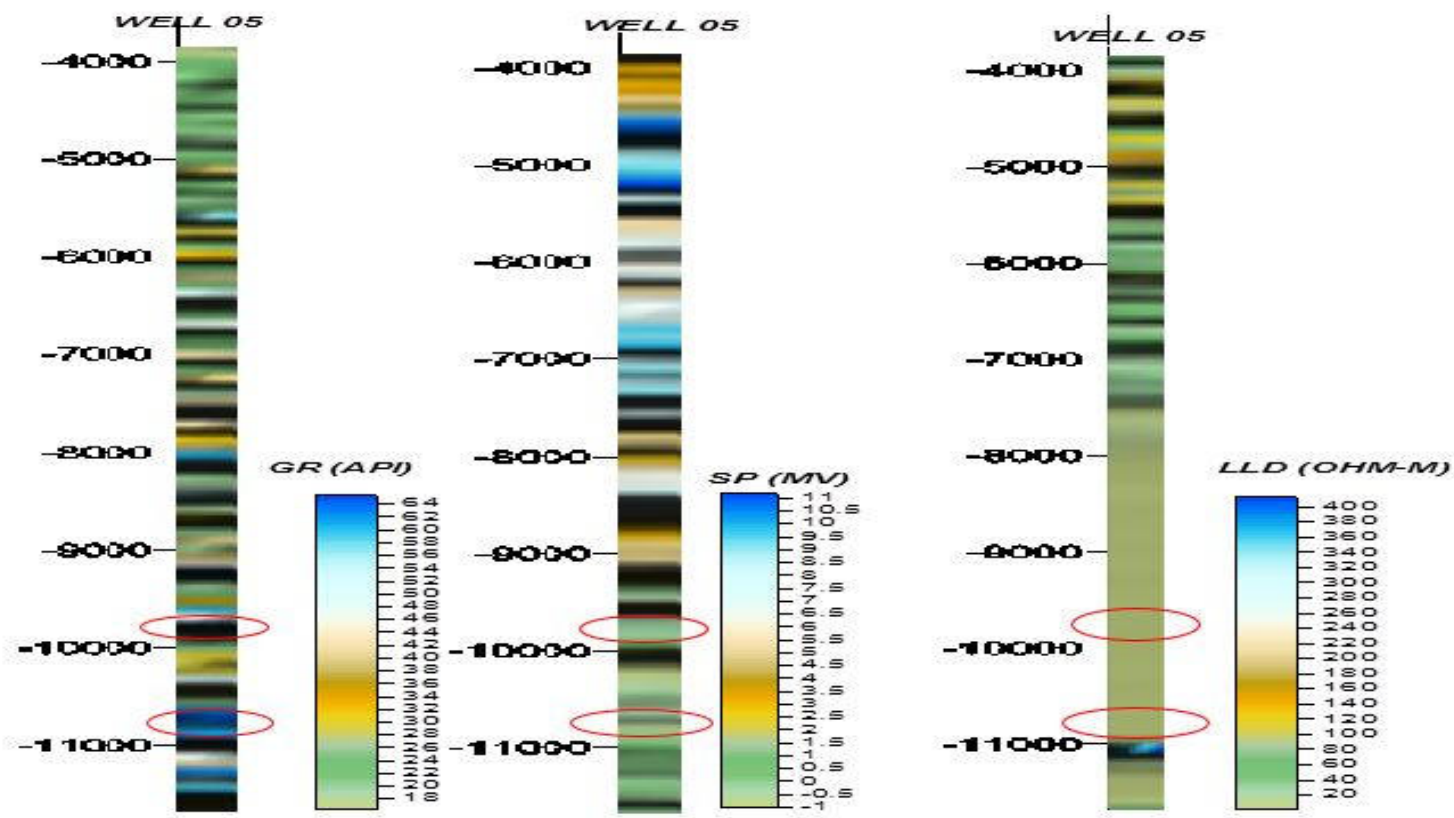

Figure 5 (d): Plot of GR, SP and Resistivity log of Well 05. The red circled spot shows the depth interval picked in well 01 and well 02 above. 


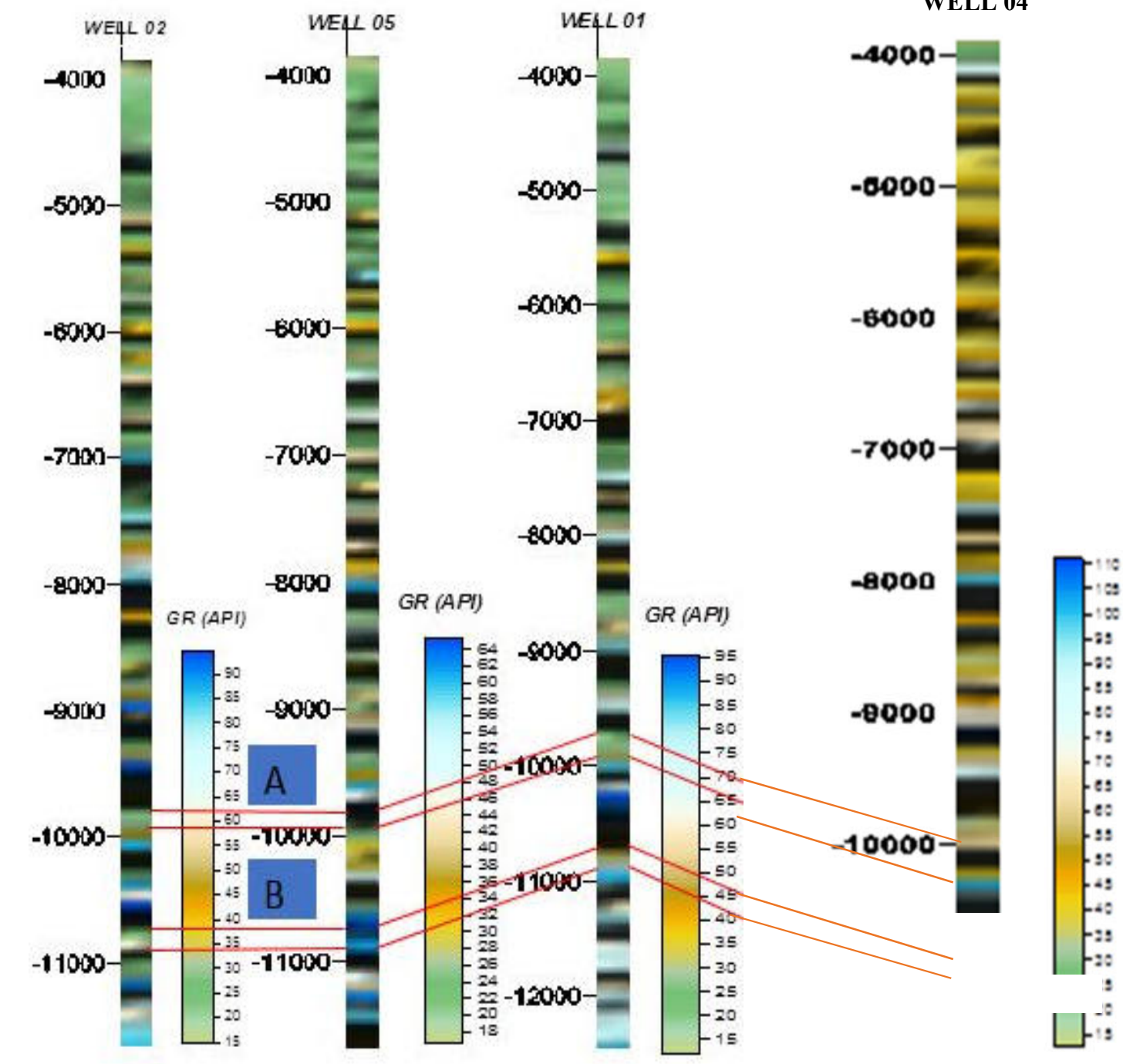

WELL 04

Figure 6: GR $\log$ of well $02,05,01$ and 04 correlated. The correlation shows changes in lithofacies across the wells at the various intervals. 


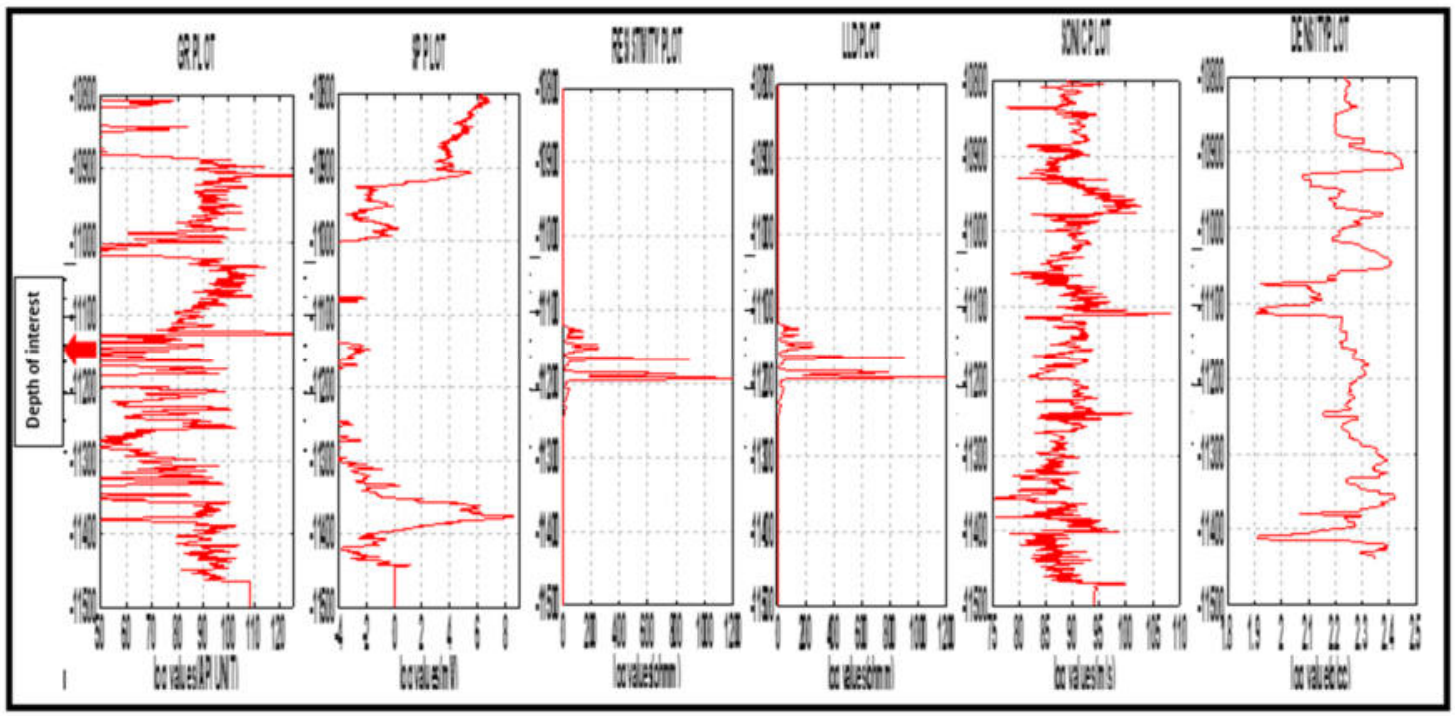

Figure 7: A correlation of GR, SP, LLD, SONIC and DENSITY log plots used to define the geologic window indicating presence of hydrocarbon at depth of $11,135.61 \mathrm{ft}-11,210.35 \mathrm{ft}$.

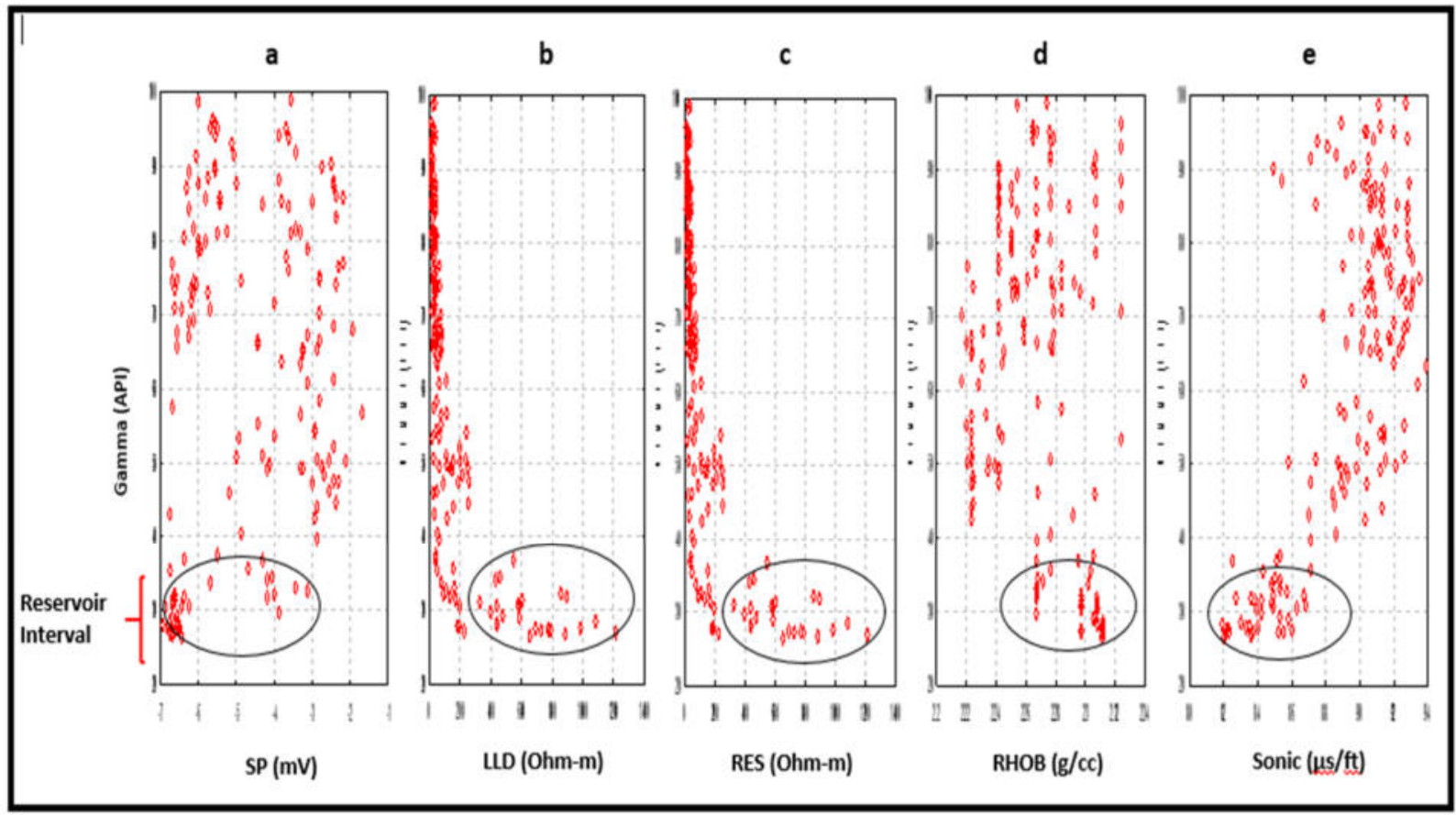

Figure 8: Cross plots of GR log against (a) SP $\log$ (b) LLD (c) Density and (d) Sonic log for well-04 to check the accuracy of the reservoir window chosen for well 04 . The crossplot gave a convergence in interpretation (black circle) which agrees in behavior within a reservoir window. 


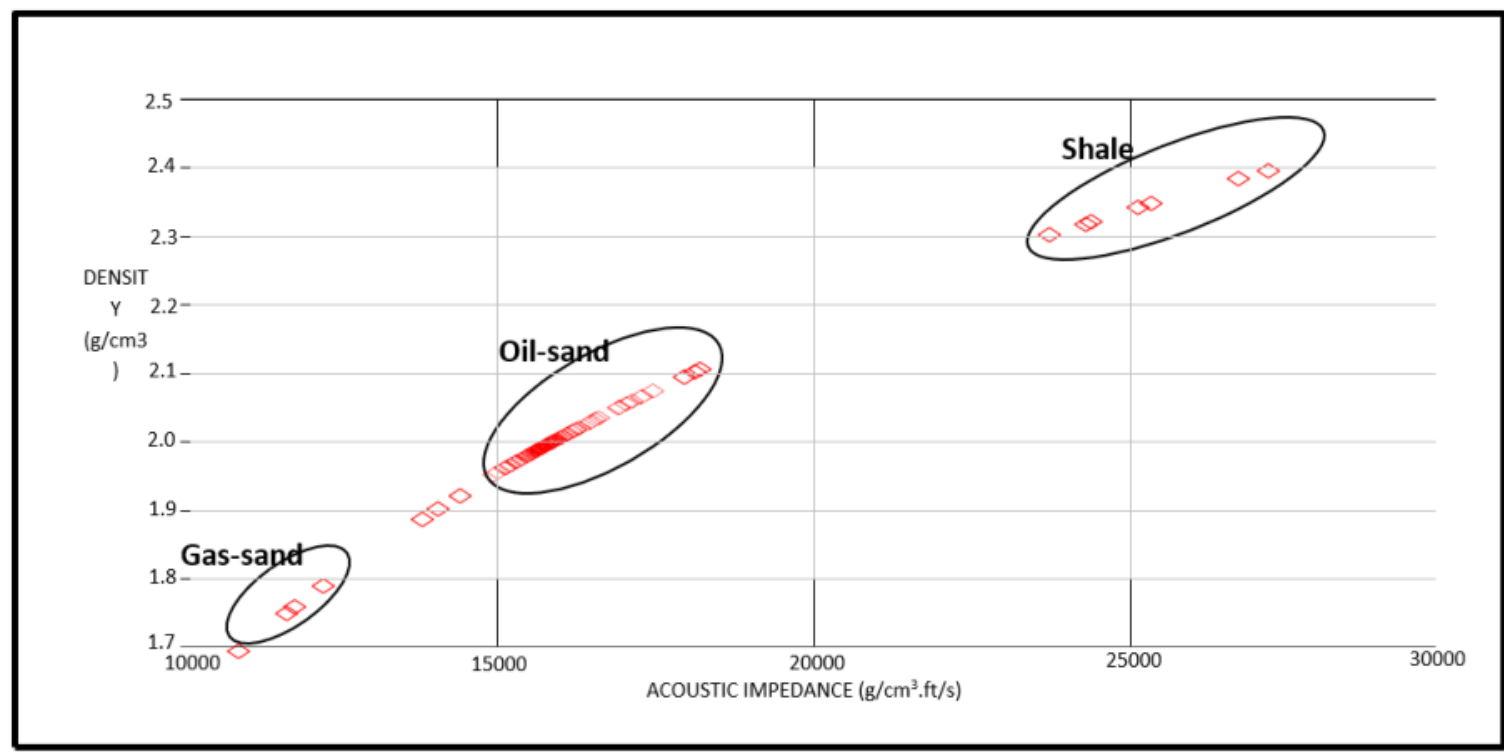

Figure 9: Crossplot of Acoustic impedance (measured and derived) against Density across the reservoir bed. The figure shows three compartments i.e. Gas-sands, Oil-sand and shale. Interpretation was done using the table 1 proposed by Dobrin (1988).

Table 1: Typical variations in Gulf coast (Onshore \& Offshore) and Niger delta in young unconsolidated sediments (After Dobrin, 1988).

\begin{tabular}{|l|c|c|}
\hline \multicolumn{1}{|c|}{ Materials } & $\begin{array}{c}\text { Velocities } \\
(\mathrm{ft} / \mathrm{sec})\end{array}$ & Densities $\left(\mathrm{g} / \mathrm{cm}^{3}\right)$ \\
\hline Shale & 8500 & 2.50 \\
\hline Gas sand & 5700 & 2.02 \\
\hline Oil sand & 7300 & $2.0-2.270$ \\
\hline Water sand & & \\
\hline (salt water sand) & 7700 & 2.275 \\
\hline
\end{tabular}




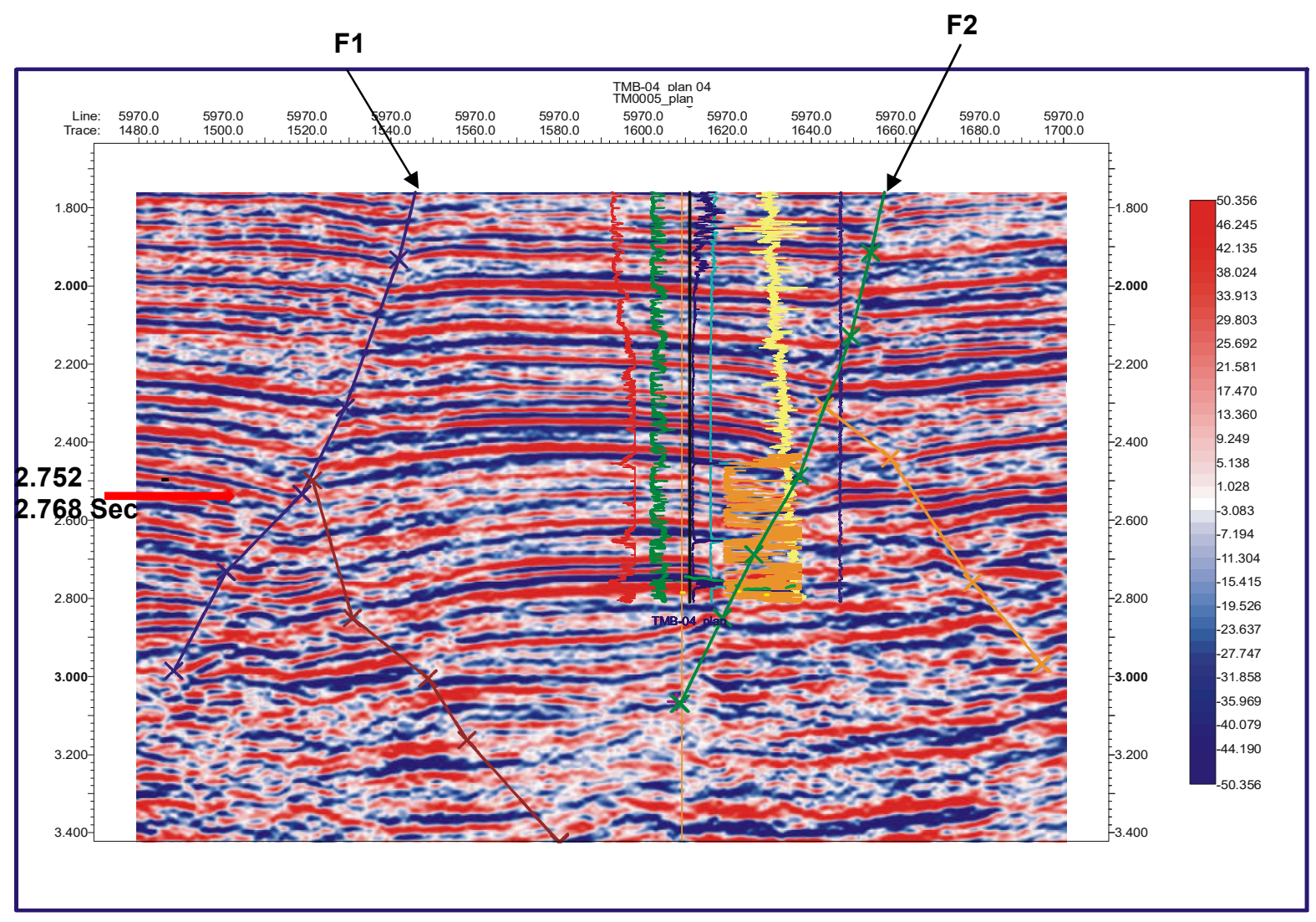

Figure 10: Arbitrary seismic line (In-line 5970) after interpretation connecting all the six (6) wells in the field. Two major faults, F1, F2 are shown bounding the wells at the reservoir interval under analysis $(2.752-2.768 \mathrm{sec}$, red arrowed). The well under reference is Well-04.

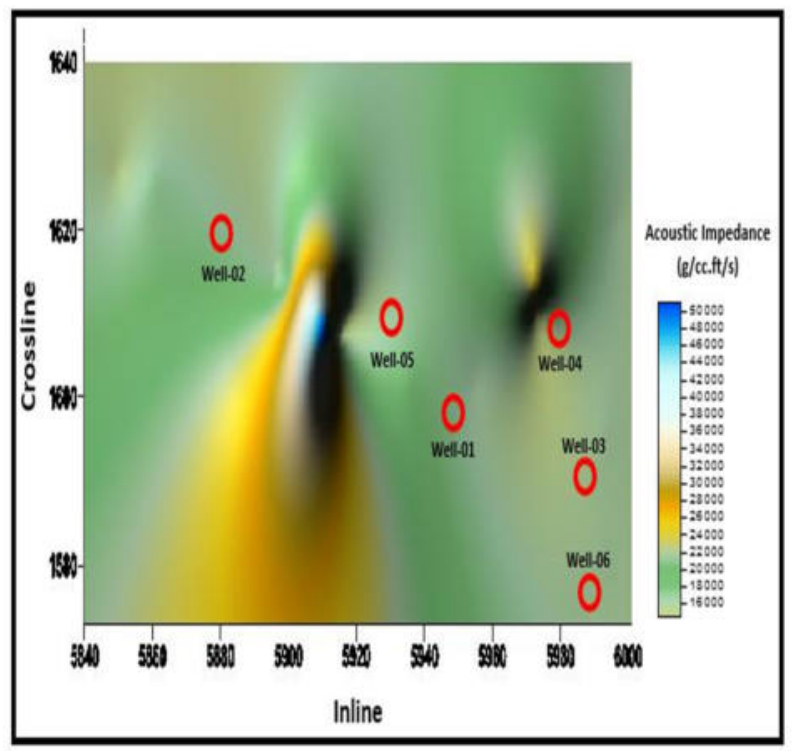

(a) 


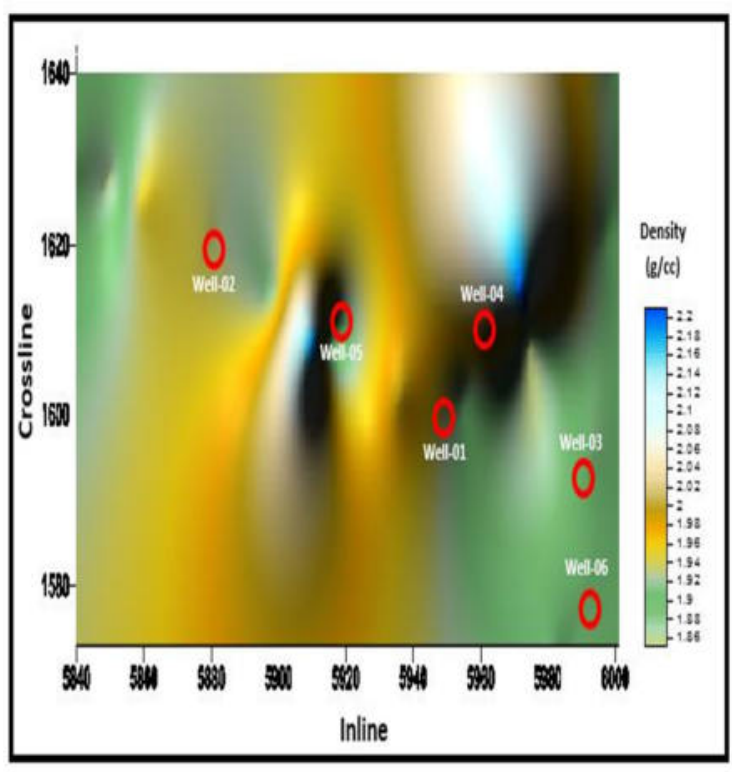

(b)

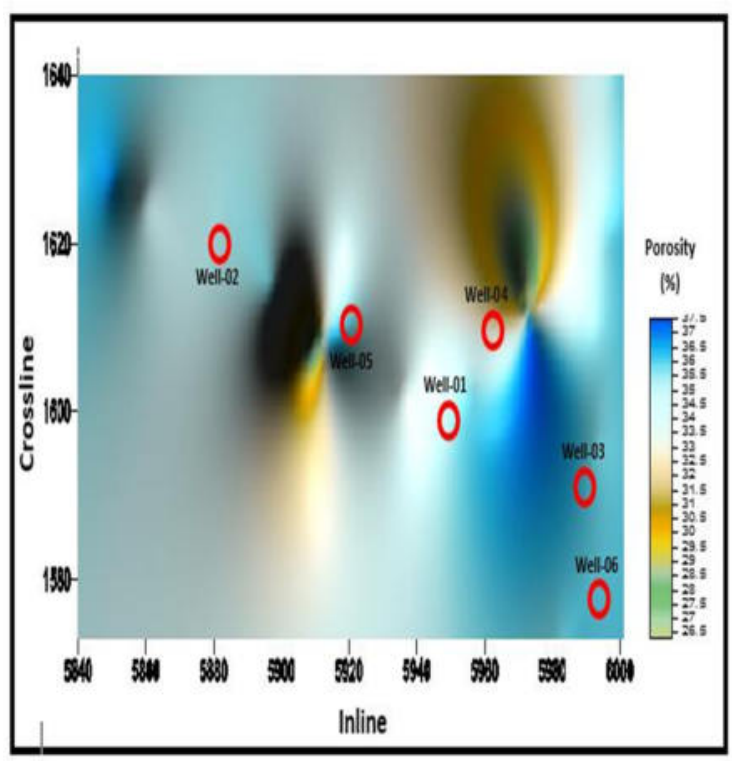

(c)

Figure 11: Comparism of (a) Acoustic impedance (b) density and (c) Porosity amplitude-time map along the arbitrary seismic line at the top $(2.752 \mathrm{sec})$ of the reservoir. The acoustic impedance in (a) is low at Well-04 (green colour band) and at other well locations indicating hydrocarbon presence, since low acoustic impedance is a seismic expression of hydrocarbon. The density values in (b) is low (about $1.86-2.06 \mathrm{~g} / \mathrm{cc}$ ) at the well locations which is representative of hydrocarbon presence within reservoirs in the Niger Delta and porosity value in (c) is high at the well locations (yellow to light blue colour), about $28.5-34.5 \%$, which is expected for a prospective zone. 


\subsection{AMPLITUDE AND PHASE SPECTRA OF ACOUSTIC IMPEDANCE, DENSITY AND VELOCITY}

Amplitude and phase spectra of acoustic impedance, acoustic impedance derived density, and velocity was computed by Discrete Fourier transform (DFT) within MATLAB to obtain their mean spectral response in terms of magnitude, phase and frequency and their corresponding time slice at top $(2.752 \mathrm{sec})$ of the reservoir was produced. The dominant frequency spectrum in the dataset is about $50 \mathrm{~Hz}$ as the amplitude plots (ABS. MAGNITUDE) were symmetrical at 50Hz. Spectral analysis was carried out decomposition using discrete Fourier transform (DFT) technique, to enhance our interpretation for stratigraphic studies. Stratigraphic features at the reservoir window are below seismic resolution due to low frequencies, hence will require frequency enhancement techniques to improve their frequency spectrum for detailed analysis Frequency maps of acoustic impedance, density and velocity were computed at top of the reservoir $(2.752 \mathrm{sec})$ by discrete Fourier transform (DFT).

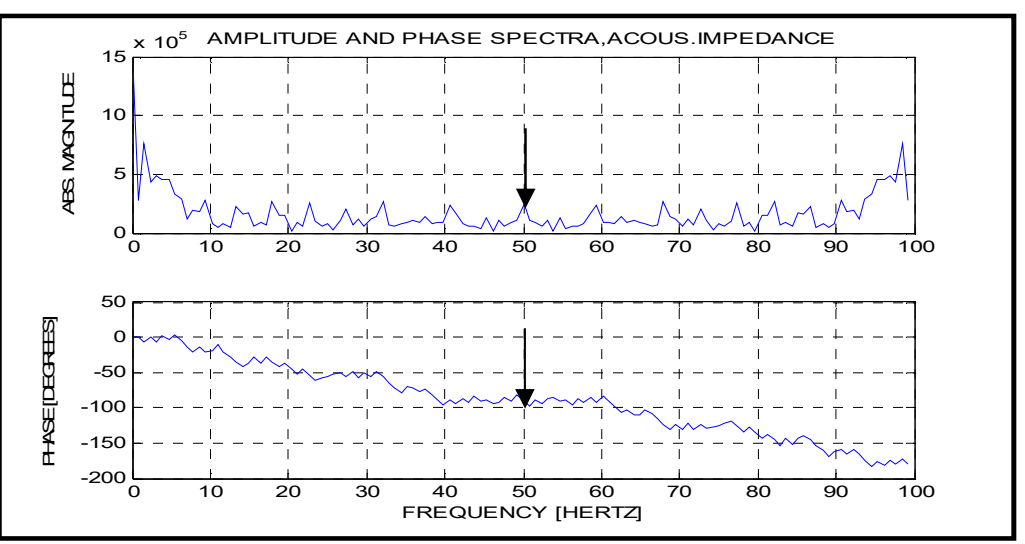

(a) Amplitude and Phase Spectra of Acoustic Impedance by Discrete Fourier Transform (DFT). Plot is symmetrical at $50 \mathrm{~Hz}$ frequency.
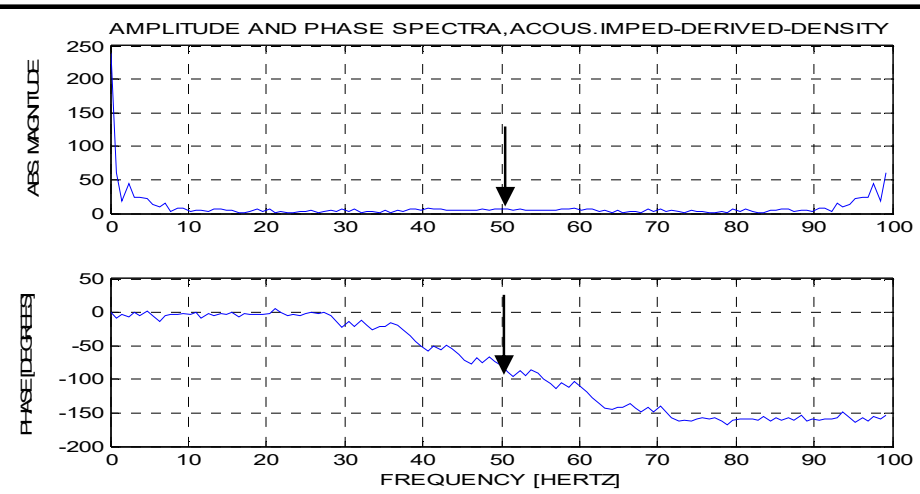

(b) Amplitude and Phase Spectra of Acoustic Impedance derived density by Discrete Fourier Transform (DFT). Plot is symmetrical at $50 \mathrm{~Hz}$ frequency. 

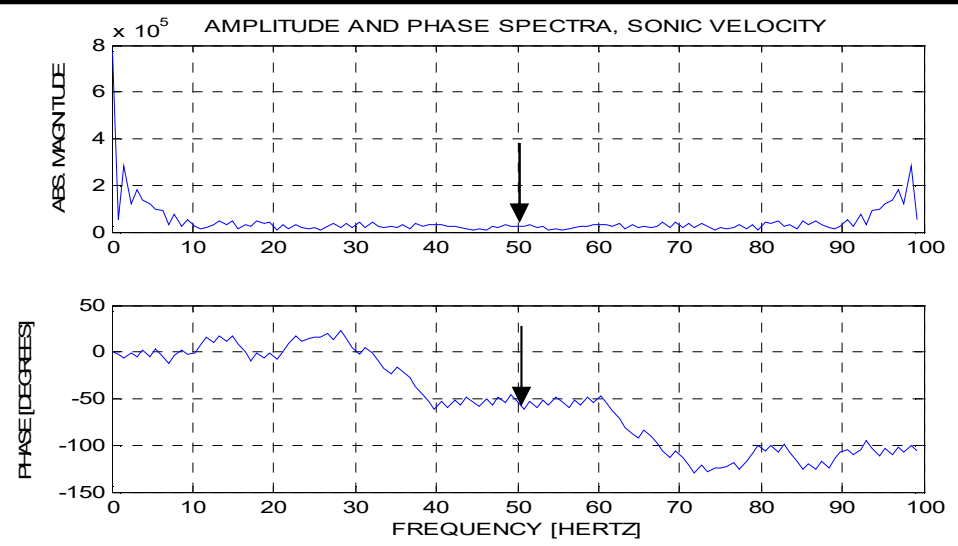

(c) Amplitude and Phase Spectra of acoustic Velocity by Discrete Fourier Transform (DFT). Plot is symmetrical at $50 \mathrm{~Hz}$ frequency.

Figure 12: (a): Amplitude and Phase Spectra of Acoustic Impedance by Discrete Fourier Transform (DFT); (b): Amplitude and Phase Spectra of Acoustic Impedance derived density by Discrete Fourier Transform (DFT); (c): Amplitude and Phase Spectra of acoustic velocity by Discrete Fourier Transform (DFT). The magnitude plots are symmetrical at $50 \mathrm{~Hz}$ frequency, hence the dominant useful frequency is about $50 \mathrm{~Hz}$.

The mean spectra response of acoustic impedance, density and velocity, in terms of magnitude, phase and frequency were presented in time slice at the top of the reservoir $(2.752 \mathrm{sec})$ using discrete Fourier transform (DFT) technique. See figures 13, 14 and 15 below. 


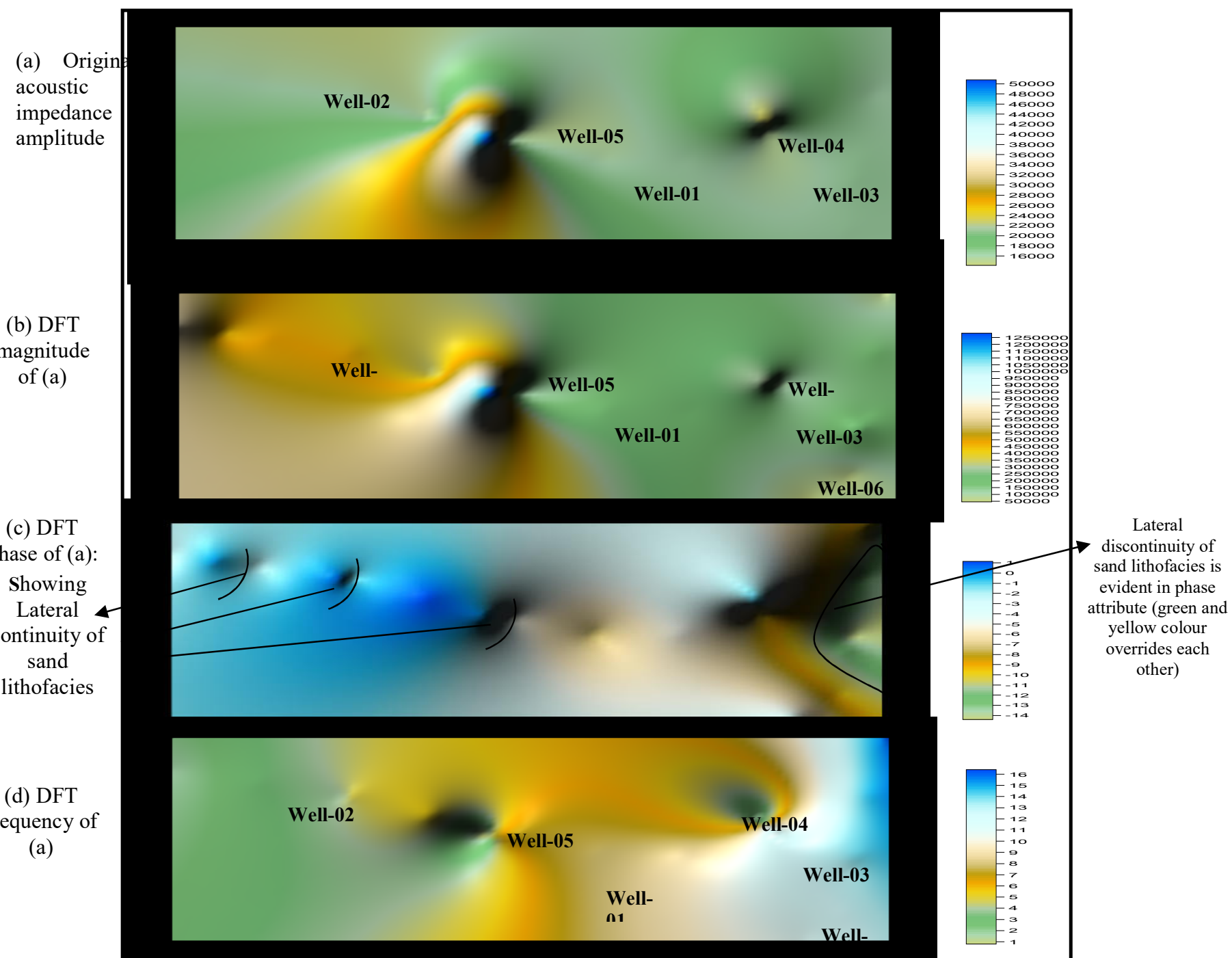

Figure 13: Acoustic impedance map at top $(2.752 \mathrm{sec})$ across reservoir bed in time and spectra domains: From top (a) Acoustic impedance amplitude (in time domain) (b) Acoustic impedance magnitude of "a"; (c) Acoustic impedance phase of "a"; (d) Acoustic impedance frequency of "a". From the map low impedance frequency seen at well-02, well-05, well-01 and well-04 locations (green-yellow colour) is diagnostic to presence of hydrocarbon. Therefore for field development, drilling direction should be directed more to the west on the green zones. 
(a)

Original

density amplitude in time

(b) DFT Magnitude of (a)

c)DFT Phase

Density

phase,

showing

Lateral

discontinuity

in lithofacies.

Segmentation

in density is

enhanced by phase values on DFT.

(d) DFT

Frequency of (a)

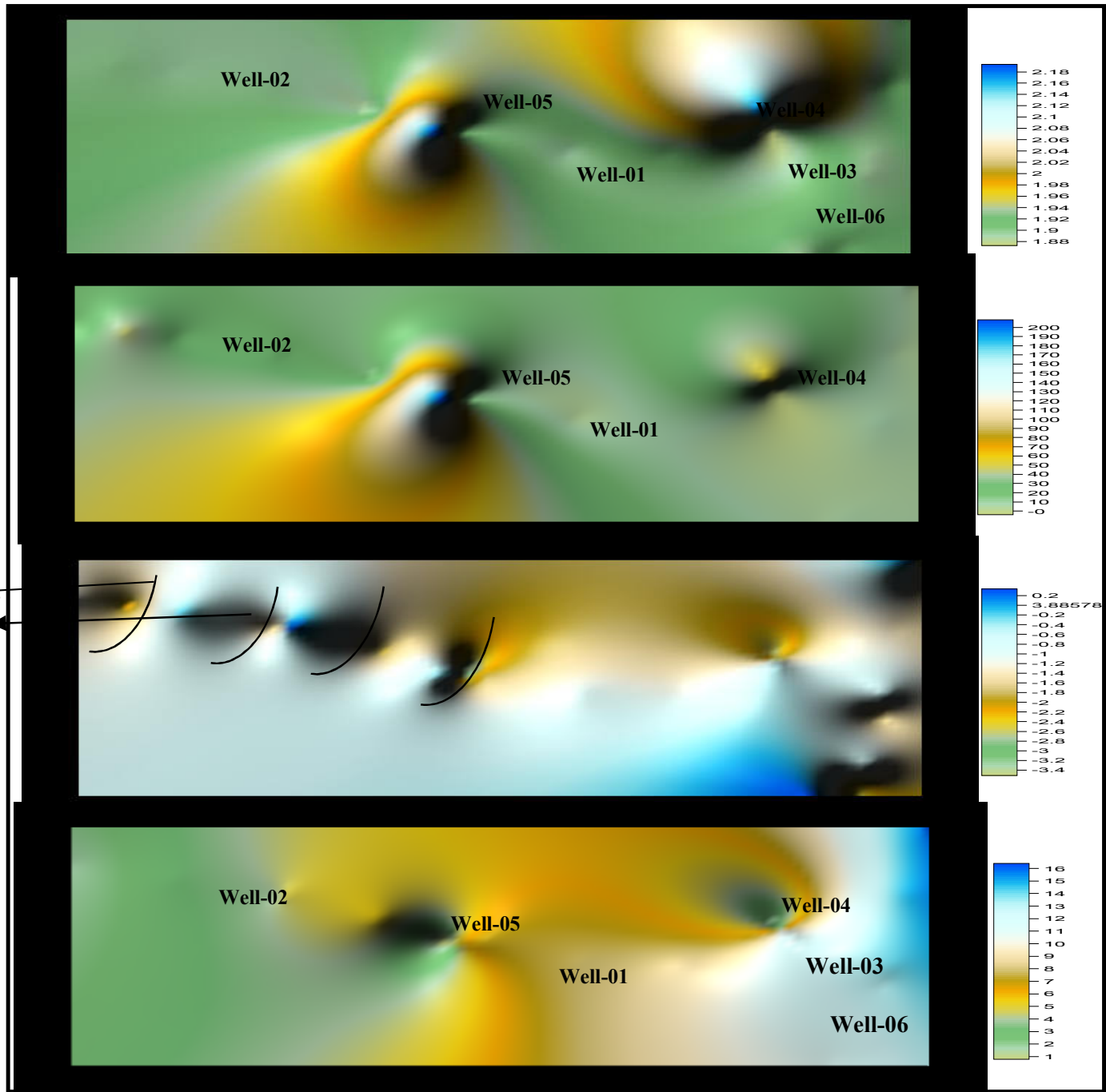

Figure 14: Density map at top (2.752sec) across reservoir bed in time and spectra domains: From top (a) Density amplitude (in time domain) (b) Density magnitude of "a"; (c) Density phase of "a"; (d) Density frequency of "a". The phase attribute in (c) shows lateral discontinuity in sand lithofacies within the reservoir which is not evident in a, b, $\mathrm{d}$ above. Low density frequency is seen at well-02, well-05, well-01 and well-04 locations (green-yellow colour) and indicates sand zones while high frequency zones indicates presence of thin shale bedding. 


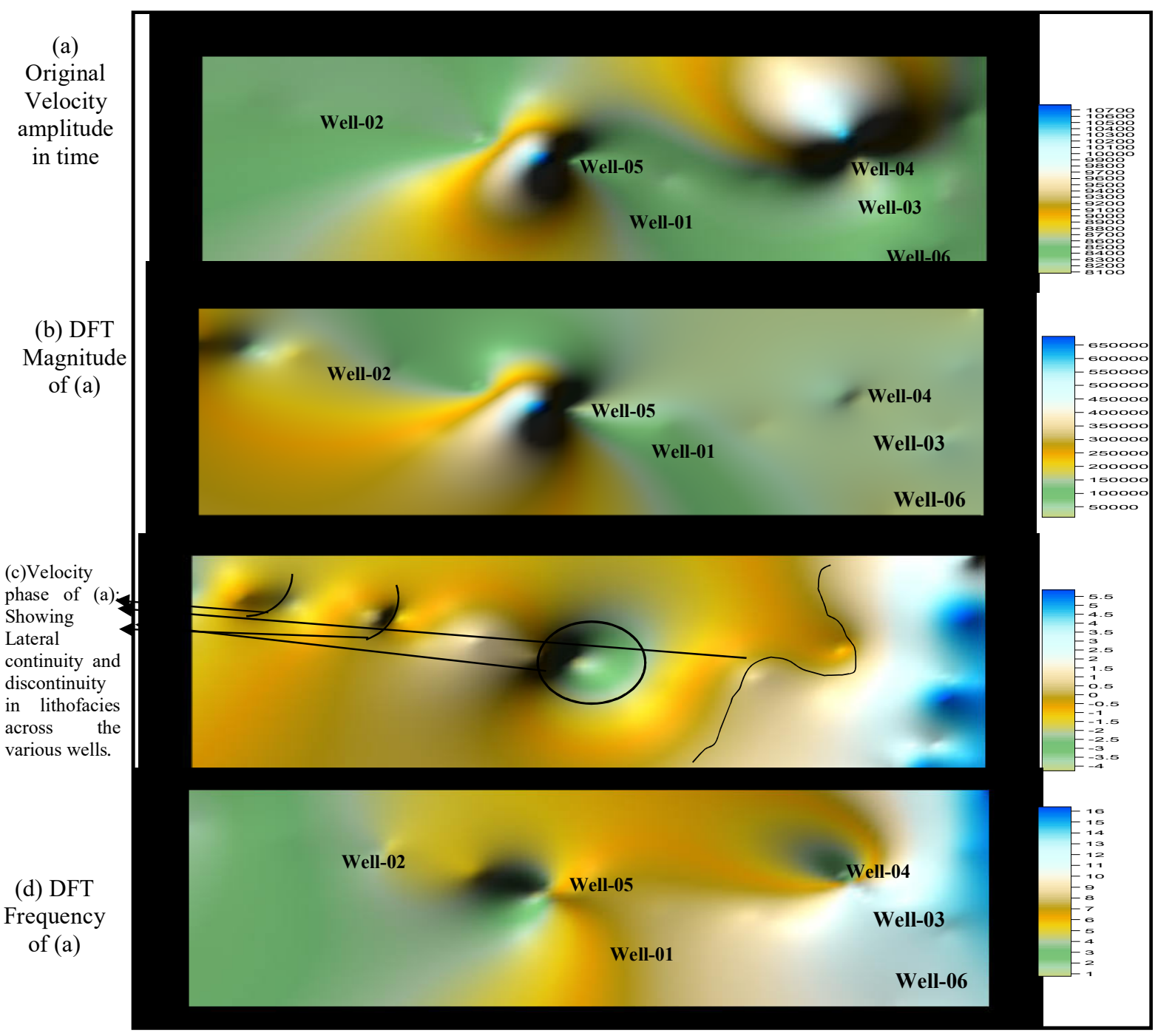

Figure 15: Velocity maps at top $(2.752 \mathrm{sec})$ across reservoir bed in time and spectra domains: From top (a) Velocity amplitude (In time domain) (b) Velocity magnitude of "a"; (c) Velocity phase of "a"; (d) Velocity frequency of "a". Low velocity frequency seen at well-02, well-05, well-01 and well-04 locations (green-yellow colour) is diagnostic to presence of hydrocarbon. The low velocity frequency zones represents the sand zones while high velocity frequency represents thin shale beddings. Therefore drilling decisions should be made at the low frequency green zones (west) for field development.

\section{DISCUSSION OF RESULTS}

Figures 5 (a-d) is the plot of GR, SP and resistivity $\log$ (LLD) for wells $04,02,01$ and 05 . In well-04 (reference well) the reservoir window of interest is between 11,135.61-11,210.35ft while for the other wells (well 02,05 and 01 ) the sand interval picked is from 10,000-11,000ft (in red circle). Figure 6 shows the GR log correlation for wells $02,05,01$ and 04 within their respective intervals. The correlation shows changes in lithofacies across the 
wells which differ in thickness due to erosion, faulting or differential rates of gravitational slumping that occurred at the various depth intervals. Figure 7 is a well log plot panel of GR, SP, RES, SONIC and DENSITY of the test data (well-04) used to map out the hydrocarbon bearing zones in the reference well which is from 11,135.61$11,210.35 \mathrm{ft}$ and is taken as the reservoir window of interest in this study. Figure 8 is a crossplot of gamma ray log against SP(mv), RES(ohm-m), density (RHOB) and sonic $\log (\mu \mathrm{s} / \mathrm{ft})$ and was used as a control to ascertain the reservoir window chosen for well 04 . The crossplot gave a convergence in interpretation (black circle) which agrees in behaviour within a reservoir window. Figure 9 is a crossplot of measured (at well location) and derived (from seismic amplitude) acoustic impedance against density dataset. The crossplot shows three distinct compartments in sand-shale lithofacies with predominant sand content across the reservoir bed and interpreted as gas filled sand, oil filled sand and shale based on table 1 proposed by Dobrin, 1988. The lithofacies showed lateral continuity across the reservoir bed. Figure 10 is the seismic section after interpretation for Inline 5970 connecting all the wells. Two faults (F1 and F2) were seen bounding the wells within the reservoir interval 2.752-2.768sec, these structures are favorable for hydrocarbon accumulation and indicates the presence of hydrocarbon within the interval. Acoustic impedance, density and porosity slice at top $(2.752 \mathrm{sec})$ of the reservoir is shown in figure 11 and suggests that the top of the reservoir for wells 01-06 contains low-impedance gas filled sand lithofacies which is laterally continuous across the reservoir bed.

Frequency maps of acostic impedance, density and velocity at top $(2.752 \mathrm{sec})$ of the reservoir are presented in figures 13 (b, c and d), 14 (b, c and d) and 15 (b,c and d) respectively. Figures 13(a), 14(a) and 15(a) are the original acoustic impedance, density and velocity amplitude values in time domain at top of the reservoir (2.752sec), while figures 13(b,c and d), 14(b,c and d) and 15(b,c and d) are the response attributes and spectral derivatives of (a) in terms of magnitude, phase and frequency. The magnitude attibute shows gas accumulations, sequence boundaries and lithofacies variations within beds. Phase attribute shows lateral continuity and discontinuity of lithfacies, it shows beddings very well along a horizon. Phase attributes is independent on amplitude, hence it should not change in principle along a horizon. However, changes arise if the lithofacies within a layer changes lateral which can be caused by "sink-holes" or changes in bedding configurations. Frequency attibute correspondes to the average frequency of the amplitude spectrum of the seismic wavelet. Low frequency is an indicator of hydrocarbon or sand rich beddings, while high frequency indicates thin shale beddings, hence frequency attribute is a bed thickness indicator. This interpretation was taken after subramanyam and Rao 2008, Jenkins and Watts 1968. In figure 13(c) (acoustic impedance phase), we noticed the lateral continuity in sand lithofacies in the various well locations which is not evident in figure 13(a,b and d). Also in figures 14(c) and 15(c) (density phase and velocity phase respectively), the lateral discontinuity and continuity of sand lithofacies were evident in both figures respectively which suggests that phase attribute is the best indicator of lateral continuity and discontinuity in beds. Also a close look at figures 13(d), 14(d) and 15(d) (acoustic impedance frequency, density frequency and velocity frequency respectively) shows that the top of the reservoir for wells 02, 05, 01 and 04 have a characteristics low values and suggests potential zones for hydrocarbon production and development in the field, while wells 03 and 06 within the same time slice $(2.752 \mathrm{sec})$ showed a higher value in acoustic impedance frequency, density frequency and velocity frequency and suggests the presence of thin shale facies at the top $(2.752 \mathrm{sec})$ of the sand reservoir. The frequency maps give better geologic image and shows lithofacies changes within stratigraphic units better than their amplitude time maps. 


\section{CONCLUSION}

This study have applied an integrated approach which combines seismic amplitude inversion, geologic transform and spectral decomposition of amplitude derived seismic attributes and well-logs for lithofacies differentiation within the Niger Delta "TOMBOY" field and results obtained show improved understanding of the concept of vertical and lateral continuity of sand lithofacies within the reservoir window because geoscientists before now had few clues about the presence of lateral continuity of sand lithofacies. From the results obtained, it is evident that the reservoir interval under analysis is made up of various lithofacies which includes gas filled sands, water-sands, oil filled sands and thin shale beds. Acoustic impedance derived from seismic amplitude inversion, improved the seismic visibility and resolution of the various lithofacies delineated within a thin-sand reservoir (of $16 \mathrm{~ms}$ in thickness). Acoustic impedance inversion improved the resolution of the interval velocity values computed within the thin-sand reservoir to a reasonable level of accuracy comparable to sonic velocity. Rock properties such as acoustic impedance, interval velocity, density, and porosity, serves as useful tools for drawing relevant geologic conclusions from the interpretation of seismic data and are theoretically the best for lithofacies differentiation, hydrocarbon delineation and reservoir characterization and particularly more in spectral (frequency) domain. The implication of this study is that by defining the lateral and vertical distribution of sand lithofacies within the reservoir bed, seismic stratigraphic studies in the field will be enhanced and hydrocarbon fairways are better defined and knowledge of this can be incorporated into drilling decisions.

\section{Acknowledgements}

We wish to express our gratitude to Chevron Corporation Nigeria, for making the Seismic and well data from TOMBOY field available for use. We are also indebted to shell Nigeria for the use of the Kingdom Suite Software at its work station and to the University of Port Harcourt and Federal University of Petroleum Resources Effurun, Nigeria for the use of her computing facilities.

\section{REFRENCES}

Adeoye, T. O. and Enikanselu, P.A. (2009). Hydrocarbon Reservoir Mapping and Volumetric Analysis Using Seismic and Borehole Data over "Extreme" Field, South western Niger Delta. Ozean Journal of Applied Sciences 2(4), p. 429-440.

Aigbedion, I. and Iyayi, S.E., (2007). Formation evaluation of Oshioka field using geophysical well logs. Middle-East Journal of Scientific Research, 2(4), p.107-110.

Avbobvo, A. A. (1978). Tertiary lithostratigraphy of Niger Delta: American Association of Petroleum Geologists Bulletin, v. 62, p. 295-300.

Branchs, R.E. and Michelena, R.J., (2002). From 3D seismic atrributes to pseudo-well-log volumes using neural networks: Practical considerations. The Leading Edge, 21(10), p.996-1001.

Boisse, S., (1978). Calculation of velocity from seismic reflection amplitude. Geophysical Prospecting, 26(1), p.163-174.

Castagna, J. P., S. Sun, and R. W. Siegfried, (2003). Instantaneous spectral analysis: Detection of low-frequency shadows associated with hydrocarbons: The Leading Edge, 22, p. 120-127.

Corredor, F.; Shaw, J. H., and Bilotti, F. (2005). Structural styles in the deepwater fold and thrust belts of the Niger Delta: American Association of Petroleum Geologist Bulletin, v. 89, no. 6, pp. 753-780.

Dobrin, M. B., Savit, C. H., (1988). Introduction to geophysical prospecting, $4^{\text {th }}$ edition, New-York, Mc GrawHill, p. 72-84.

Doust, H. and E. Omatsola, (1989). Niger delta. AAPG Memoir 48; p. 201-238.

Doust, H. and Omatsola, E., (1990). Niger Delta, in Edwards, J.D, and Santogrossi, P.A., eds; Divergent/passive Margin basins; AAPG Memoir 45; p. 239-248. 
Ejedawe, J.E., (1981). Patterns of incidence of oil reserves in Niger Delta Basin. AAPG Bulletin, Vol. 65, p. 15741585 .

Evamy, B.D., J. Haremboure, R. Kammerling, W.A. Knaap, F.A. Molloy, and P.H. Rowlands, (1978). Hydrocarbon habitat of tertiary Niger Delta. AAPG Bulletin; Vol.62, no.1, p. 1 - 39.

Hansen, T. M., Mosegaard, K. Pedersen-Tatalovic, R., Uldall, A., and Jacobsen, N. L., (2008). Attributeguided well-log interpolation applied to low-frequency impedance estimation, Geophysics, vol. 73, no. 6; November-December 2008; p. R83-R95.10.1190/1.2996302.

Jenkins, G.M and Watts. D.G. (1968). Spectral analysis and its applications, Published by Boca Raton, Fl.: Emerson-Adams Press 525P, http://trove.nla.gov.au/version/39694417.

Lavergne, M., and William, C., (1977). Inversion of seismograms and pseudo-velocity logs: Geophys. Prosp., v. 25 p. $232-250$.

Lindseth, R. O., (1979). Synthetic sonic logs-a process for stratigraphic interpretation. Geophysics, 44(1), p. 3-26.

Mitchum, A. A., Cross, T. A., Homewood, P. F., (1997). Seismic Stratigraphy and Global Changes of Sea Level, Part 6: Stratigraphic Interpretation of Seismic Reflection Patterns in Depositional Sequences. In Seismic Stratigraphy-Applications to Hydrocarbon Exploration (C. E. Payton, Ed.), American Association of Petroleum Geologists Memoir Vol 26, p. 117-133.

Ofuyah, W., O. Orji, and E. Stanley, (2015). The Application of Spectral Decomposition to 3-D Seismic Data over 'X'-Oil Field, Niger Delta: Geosciences 2015, Vol 5, p. 86-99.

Opara A.I., (2010). Prospectivity Evaluation of "Usso" Field, Onshore Niger Delta Basin, Using 3-D Seismic and Well Log Data. Petroleum and Coal, 52 (4) p. 307-315.

Petroconsultants, (1996). Petroleum exploration and production database: Houston.

Schlumberger, (1987). Log Interpretation Principles/Application. Schlumberger Wireline \& Testing, Texas.

Sheriff, R. E., (1976). Inferring stratigraphy from seismic data. AAPG Bulletin, 60(4), p. 528-542.

Short, K. C. and A. J. Stauble, (1967). Outline of geology of Niger Delta. AAPG Bulletin, Vol. 51, no.5, p. 761 -779 .

Subramanyam, D. and Rao, P.H. (2008). Seismic Attributes: A Review, 7th International Conference \& Exposition on Petroleum, Geophysics, Hyderabad, p. 398 - 404.

Telford, W.M., Geldart, L.P. and Sheriff, R.E., (1990). Applied geophysics (Vol. 1). Cambridge University press London, $3^{\text {rd }}$ ed., p. 769.

Ukaigwe, N. F. (2000). A first course in Seismic exploration, Eddy-Joe publishers, Nigeria Ughelli, Port Harcourt. $2^{\text {nd }}$ ed., p. 85-86 and p. 367-372.

Weber, K.J. and E.M. Daukoru, (1975). Petroleum Geology of the Niger Delta. Proceedings of the 9th World Petroleum Congress, Tokyo. Applied science publishers, Ltd, London. Vol. 2, p. 202-221.

Widess, M.B, (1973). How thin is a thin bed? Geophysics, 1973, No.6, vol. 38 p. 17-20.

Yilmaz, O. (2001). Seismic data processing, society of exploration geophysicists, Tulsa Oklahoma. 